\title{
有機溶媒による絹布の膨潤*1
}

\author{
京都工芸䄉維大学工芸学部 林 良之・清水 富男・老田 達生・ \\ 樽井 栄満·谷口由希子 \\ 京都府織物 指 導所 岡川 逸郎 - 浅井 紀夫 \\ 日東紡績 (株)加工研究所 笹倉 忠雄
}

\section{SWELLING OF SILK FABRIC BY ORGANIC SOLVENTS*1}

\author{
Yoshiyuki Hayashi, Tomio Shimizu, Tatsuo Oida, Yoshimitsu Tarui,Yukiko Taniguchi, \\ Itsuo Okagawa*2, Norio Asai ${ }^{* 2}$, and Tadao Sasakura*3 \\ Faculty of Engineering and Design, Kyoto Institute of Technology, Matsugasaki \\ Kyoto, 606 Japan \\ *2 Kyoto Prefectural Textile Industry Guidance Center, Mineyama, Kyoto Pref., 627 \\ Japan \\ *3 Nitto Boseki Co., Nishikuwazu, Itami, 664 Japan
}

\begin{abstract}
Swelling of silk and rayon fabrics by organic solvents depended on the kind and the temperature of the solvents and the period of immersion. The degree of swelling after the shrink proofing using phosphoryl amide was comparable to that before the proofing. Dimethyl sulfoxide was one of the best sol. vents for the shrink proofing by phosphoric amides. Some of the fundamentals govering the shrinkage of silk goods were explained on the basis of the release of the strains imposed during manufacturing process. es, and the swelling produced on wetting. The mechanism of the swelling by organic solvents was ex. plained in terms of the solubility parameter of the solvents and hydrogen bonding and dipolar interactions between silk and the solvents. The most important factor for the shrink-proofing would be cross-linking between the fibers in the very vicinity under the swelling. up to $100 \%$, of the fabric by covalent bonding and / or adhesives.
\end{abstract}

(Received March 25, 1991)

\section{1. 粕 言}

我々 $(1,2)$ は絠をリンのアミド誘導体のジメチルス ルホキシド(DMSO) 溶液で処理すると絹の収縮が防止で きることを報告した。この報告の中でリンのアミド誘導 体の溶媒として種々の溶媒を用いて防縮度を調べた結 果, DMSOが最適であることが明らかになっだ。リンの アミド誘導体か防縮効果を示す機構には種々检討すべき 課題が残されているが，溶媒に大きく依存する点仗溶媒 による釉の膨潤が最大の効果と考えられる。

*1この報文を「維の防維に関する研究(第 3 報)， Studies on the Shrink-proofing of Silk (part 3)」とす る。
そこで綟織物の有機溶媒による膨潤について検討し た。有機溶媒による緗の膨潤現象について，最近北村ら 〔3〕の報告があり，この文献の中で膨潤に関する過去の 文献が紹介されている。平林（4] は有機溶刜中での絹 の収縮応力と溶媒の溶解度パラメーターとの関連を論じ

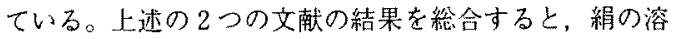
解度パラメーターの計算值12.3に近い溶媒は絹をよく膨 潤させること及び絹 - 溶媒間の相互作用は水素結合及び 双極子 - 双極子相互作用が大さく寄与すると説明されて いる。北村らの膨潤体積に関する結果と平林の収縮応力 に関する結果とは各々の溶媒で一致しない点も見られる が，この一因は膨潤中に収縮応力の緩和が起こる為上も 考えられる。上述の收縮応力，膨潤体積とも室温付近で 
䅌系について測定されている。膨潤度と温度, 時間の関 保はある程度予測可能であるが，有機溶媒を用いた綟布 の膨潤について試みられた例はない。収縮することを除 くと絹織物としては優れた物性を有する一越ちりめん及 びサテンについて前報 (2)で此較的防縮性の高い值を 与えた溶媒を用いて膨潤度と温度、時間の関倸を測定し た。この結果から防縮の機構を考察した。

\section{2. 実駼}

\section{1 試料}

1) 試験綟布は精練济みの一越ちりめん(32多目付 経系21中 3 本平采 緯采 21 中 8 本強撚采)及びサテン(経 系31中 2 本 緯糸31中 6 本)をシリカゲルの入ったデシ ケーター中に保存して用いた。

レーヨン布はスフ(モスリン。経：30番手,94本/イン 千, 緯：30番手，70本/インチ)及びフィラメント(経：

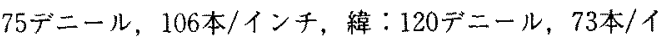
ンチ)を用いた。

2 ）溶凨は和光特級試薬をそのまま用いた。ジメチル スルホキシド(DMSO)，エチレングリコール(EG)，ジ メチルホルムアミド(DMF)を主として用いた。

\section{2 方 法}

膨潤度は礪波ら〔5〕の䄸の膨潤度の測定法に準じて 行った。約 $0.2 \mathrm{~g}$ の組織物を的 $40 \mathrm{~mL}$ の溶媒中に入れ所 定温度 $\left(40-120^{\circ} \mathrm{C}\right)$ の恒湿槽中で所定時問 $(5-60 \mathrm{~min})$ 浸 漬して膨潤させた。膨潤した蟣維を卓上型小型遠心機を 用いて3000 rpm で10 min 遠心分離して表面に付着した 溶媒を除去した。この膨潤織維を流動パラフィンを置換 媒体としてピクノメーターを用いて $30^{\circ} \mathrm{C} て ゙$ 体積を測定 した。同一条件で 3 回測定を繰り返しその平均値を求め た。今回の試験に用いた有機浴媒は流動パラフィンを殆 ど溶解しない。乾燥布の単位重量当りの膨潤布の体積を 膨潤体積 $\mathrm{V}$, 乾燥布の単位体積当りの膨潤により增加し た体積の割合 (\%)を膨潤度 S, 乾燥布の単位重量当りの 膨潤により增加した重量の割合(\%)をWで示し以下の 式で求めた。

$$
\begin{aligned}
& \mathrm{S}=\left(\mathrm{V} \cdot \rho_{1}-1\right) \times 100 \\
& \mathrm{~W}=\left(\mathrm{W}_{\mathrm{FT}} / \mathrm{W}_{\mathrm{F}}-1\right) \times 100 \\
& \mathrm{~V}=\mathrm{V}_{\mathrm{T}} / \mathrm{W}_{\mathrm{F}} \\
& \mathrm{V}_{\mathrm{T}}=\mathrm{V}_{\mathrm{P}}-\left(\mathrm{W}_{\mathrm{PT}}-\mathrm{W}_{\mathrm{PF}}\right) / \rho_{2} \\
& \mathrm{~W}_{\mathrm{F}}: \text { 乾燥試験布の重量 } \\
& \mathrm{W}_{\mathrm{FT}}: \text { 膨潤試験布の重量 } \\
& \mathrm{V}_{\mathrm{P}}: \text { ピクノメーターの容積 } \\
& \mathrm{W}_{\mathrm{PT}}: \mathrm{W}_{\mathrm{PF}} \text { に流動パラフィンを满たした重量 } \\
& \mathrm{W}_{\mathrm{PF}}: \text { 空のピクノメーターに处理試験布を入れた時の }
\end{aligned}
$$

$\rho_{1}: 30^{\circ} \mathrm{C} に$ に打る布の比重(パラフィン置換によ る)

$\rho_{2}: 30^{\circ} \mathrm{C}$ におけるパラフィンの比重 $(0.872)$

上記の操作で求めた乾燥試験布一越ちりめん，サテン (精練 3 月後)いずれの $\mathrm{V} も 0.820\left(\mathrm{~cm}^{3} / \mathrm{g}\right)$ であり, 従っ て密度は $1.22\left(\mathrm{~g} / \mathrm{cm}^{3}\right)$ と諳算される。

\section{3. 実験結果と考察}

\section{1 絹布の越潤}

サテンを用いた膨潤の結果を表 1 に示す。サテンを40 ${ }^{\circ} \mathrm{C}$ の水に10分浸漬した時の膨潤度は $28 \%$ であり, EGの それが $20 \%$ に対し DMSO，DMFのそれが極端に小さい 值であることは注目される。浸漬終了から遠心分㒕機の 最高回転数到達までに 2 分余り要するが，膨潤温度が80 ${ }^{\circ} \mathrm{C}$ 以上では浸漬 5 分程度で膨潤平衡に達する場合が多 い。DMFの場合，この温度に扔いても浸漬時間と共に 少し膨潤度の增加傾向がある。体積增加率と重量增加率 はほほ同じ傾向を示すが，一般に前者の方が大きな值を

\begin{tabular}{|c|c|c|c|c|c|c|}
\hline \multirow{2}{*}{ Solvent } & \multirow{2}{*}{ Temp. $\left({ }^{\circ} \mathrm{C}\right)$} & \multicolumn{5}{|c|}{ Immersion time (min) } \\
\hline & & 5 & 10 & 15 & 30 & 60 \\
\hline \multirow[t]{6}{*}{ DMSO } & 40 & 0 & 6 & 12 & 17 & 35 \\
\hline & $40\left(W^{a}\right)$ & 21 & 22 & 29 & 32 & 46 \\
\hline & 80 & 100 & 102 & 102 & 102 & 105 \\
\hline & 100 & 112 & 113 & 113 & 112 & 113 \\
\hline & $100\left(W^{a}\right)$ & 106 & 107 & 107 & 108 & 107 \\
\hline & 120 & 109 & 111 & 112 & 113 & 112 \\
\hline \multirow[t]{4}{*}{$\mathrm{EG}$} & 40 & 16 & 20 & 24 & 27 & 44 \\
\hline & 80 & 60 & 60 & 60 & 60 & 61 \\
\hline & 100 & 61 & 61 & 60 & 60 & 61 \\
\hline & 120 & 61 & 62 & 63 & 62 & 62 \\
\hline \multirow[t]{6}{*}{ DMF } & 40 & 1 & 2 & 2 & 2 & 5 \\
\hline & $40\left(W^{a}\right)$ & 1 & 2 & 2 & 2 & 3 \\
\hline & 80 & 22 & 35 & 40 & 43 & 45 \\
\hline & 100 & 34 & 39 & 39 & 38 & 41 \\
\hline & $100\left(W^{2}\right)$ & 29 & 30 & 31 & 30 & 32 \\
\hline & 120 & 35 & 38 & 38 & 39 & 41 \\
\hline
\end{tabular}
示す。しかし，DMSO 中 $40^{\circ} \mathrm{C}$ の膨潤の際に体積の变化 は小さいのに重量はかなり増加している。一越ちりめん を用いた場合にも表 2 に示すように同様な結果が得られ た。

表 $1 ， 2$ の膨潤度の測定に用いた綟布を 1 年余り室温 で空気中に放置後、この布について再測定を行った結果

Table 1 Degree of Swelling (S) of Silk Satin by Organic Solvents

\footnotetext{
a) Degree of swelling $W$
} 
Table 2 Degree of Swelling (S) of Silk Crepe (Hitokosi)

\begin{tabular}{lcrrrr}
\hline \multirow{2}{*}{ Solvent } & Temp. $\left({ }^{\circ} \mathrm{C}\right)$ & \multicolumn{5}{c}{ Immersion time (min) } \\
\cline { 3 - 6 } & & 5 & 10 & 15 & 30 \\
\hline \multirow{2}{*}{ DMSO } & 100 & 100 & 99 & 99 & 100 \\
& 120 & 99 & 100 & 99 & 100 \\
\hline \multirow{2}{*}{ EG } & 100 & & 76 & & \\
& 120 & & 77 & & \\
\hline \multirow{2}{*}{ DMF } & 100 & 39 & 39 & 40 & 44 \\
& 120 & 39 & 40 & 40 & 42 \\
\hline
\end{tabular}

Table 3 Degree of Swelling (S) of Silk Satin (reproducibility test)

\begin{tabular}{lrrrrrr}
\hline \multirow{2}{*}{ Solvent } & & \multicolumn{5}{c}{ Immersion time (min) } \\
\cline { 3 - 7 } & & \multicolumn{1}{c}{5} & 10 & 15 & 30 & 60 \\
\hline DMSO & 40 & 18 & 24 & 26 & 28 & 41 \\
& 80 & 76 & 80 & 86 & 89 & 92 \\
& 100 & 89 & 91 & 95 & 95 & 95 \\
\hline EG & 40 & 17 & 20 & 26 & 26 & 39 \\
& 80 & 42 & 50 & 51 & 57 & 62 \\
\hline DMF & 40 & 4 & 7 & 9 & 9 & 10 \\
& 80 & 22 & 29 & 32 & 37 & 37 \\
\hline
\end{tabular}

Table 4 Degree of Swelling of Silk Crepe (reproducibility test)

\begin{tabular}{lcccccc}
\hline \multirow{2}{*}{ Solvent } & & \multicolumn{5}{c}{ Immersion time (min) } \\
\cline { 3 - 7 } & Temp. $\left({ }^{\circ} \mathrm{C}\right)$ & 5 & 10 & 15 & 30 & 60 \\
\hline \multirow{2}{*}{ DMSO } & 100 & 84 & 86 & 87 & 91 & 92 \\
& 120 & 91 & 91 & 91 & 90 & \\
\hline EG & 100 & 70 & 70 & 71 & 72 & 72 \\
& 120 & & 70 & & & \\
\hline
\end{tabular}

Table 5 Degree of Swelling (S) of Silk Satin by DMSO Aqueous Solution

\begin{tabular}{rrrrrrr}
\hline & & \multicolumn{5}{c}{ Immersion time $(\min )$} \\
\hline & & 5 & 10 & 15 & 30 & 60 \\
\hline 100 & 100 & 112 & 113 & 113 & 112 & 113 \\
90 & 100 & 82 & 83 & 82 & 83 & 82 \\
80 & 100 & 67 & 71 & 71 & 71 & 71 \\
0 & 100 & & 32 & & & \\
\hline
\end{tabular}

Table 6 Shrink Proofing of Silk Crepe (Hitokosi) by Phosphoryl Amide Solution

\begin{tabular}{lcc}
\hline Solvent & $\begin{array}{c}\text { Degree of shrink (\%) } \\
\text { Wegree of swelling }(\mathrm{S}) \text { immersed in } \\
\text { the solvent at } 100^{\circ} \mathrm{C} \text { for } 10 \mathrm{~min}\end{array}$ \\
\hline Water & 25 & (befor treatment) \\
DMSO & 21 & 32 \\
EG & 2.5 & 98 \\
DMF & 6.3 & 77 \\
\hline
\end{tabular}

を表 $3 ， 4$ に示す。この時のサテン，一越ちりめん共乾 燥布の $30^{\circ} \mathrm{C}$ の比重は $1.31 て ゙$ 前速の1.22加ら增加し，ま た表 $1 ， 2$ の結果より高温での膨潤度が低下している。 $40^{\circ} \mathrm{C}$ における DMSO の膨潤度は逆に增加している。1

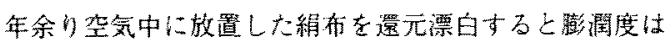
初期の值が再現されるので，水中での精練漂白で絹布の 親水性基の多い表面は疎水性の空気中で表面分子の再配 列及び酸化が進行していることが予想される。

DMSO は吸湿性の高い溶剂であり，含水DMSOによ るサテンの膨潤度を検討した(表 5 )。90\%DMSOでも $100 \%$ に比較すると膨潤度はかなり低下している。

防縮加工用樹脂としてりン酸アミドの10\%溶液(一部 㦟摆液) 用い，水溶液の場合は予借乾燥後，之の他の 溶刜を用いたときは $100 \%$ pick-up 後綃布をピンで一定 長に張り密閉容器中で $120{ }^{\circ} \mathrm{C}$, 20 分加熱後洗浄, セッ卜 乾燥した布を30分問沸腾水中に漬けその防縮度を测定し た結果表6 红示す。DMSO 溶液で防維加工した後の絹 布の膨潤度は加工前のそれと殆ど変わらない。一方加工 布の水による膨潤度は加工前より增加する。

\section{2 レーヨン布の臌潤}

リン酸アミド氷溶液のレーヨン布への pad-dry-cure によりレーヨン布に防縮性（6]を付与することが可能 である。レーヨン布(スつ，モスリンにについて絹布と同 様な膨潤实験を行った。ての結果を表７に示す。この塞 験の範囲内で各々の溶媒に対するレーヨンの膨潤举動は 絹のそれに極似している。フィラメントレーヨン布の場 合もほほ同梂な結果であった。レーヨンの水による膨澖 度は綟のそれよりかなり大きい。レーヨンのリン酸アミ ド防縮加工液を用いた場合の膨潤度は表７の下段に示す ように水上り更に大きくなる。

リン酸アミドによるレーヨンの防縮加工の詳細は省略 するが，DMF 溶液を用いては所期の防縮性能は得られ ない。DMSO 溶渡を用いた場合は，pad-dry-cure 或は 溶液含浸布何れの場合も所期の防縮性能が達成される。 
Table 7 Degree of Swelling (S) of Rayon Muslin

\begin{tabular}{|c|c|c|c|c|c|c|}
\hline \multirow{2}{*}{ Solvent } & \multirow{2}{*}{ Temp. $\left({ }^{\circ} \mathrm{C}\right)$} & \multicolumn{5}{|c|}{ Immersion time $(\min )$} \\
\hline & & 5 & 10 & 15 & 30 & 60 \\
\hline \multirow[t]{4}{*}{ DMSO } & 40 & 16 & 16 & 16 & 15 & 24 \\
\hline & 80 & 140 & 143 & 143 & 143 & 145 \\
\hline & 100 & 134 & 136 & 138 & 138 & 136 \\
\hline & 120 & & & & 134 & \\
\hline \multirow[t]{4}{*}{ EG } & 40 & 21 & 23 & 26 & 24 & 29 \\
\hline & 80 & 81 & 81 & 81 & 82 & 81 \\
\hline & 100 & 81 & 76 & 79 & 79 & 82 \\
\hline & 120 & & & & 79 & \\
\hline \multirow[t]{4}{*}{ DMF } & 40 & 7 & 7 & 7 & 9 & 11 \\
\hline & 80 & 6 & 6 & 7 & 16 & 47 \\
\hline & 100 & 39 & 41 & 47 & 48 & 56 \\
\hline & 120 & & & & 38 & \\
\hline \multirow[t]{3}{*}{ Water } & 40 & & & & 65 & \\
\hline & 80 & & & & 72 & \\
\hline & 100 & & & & 75 & \\
\hline $\begin{array}{l}1 \% \mathrm{NaOH} \\
\text { aq. soln. }\end{array}$ & 30 & & 97 & & & \\
\hline \multirow[t]{2}{*}{$13 \%$ Soln. $^{a}$} & 80 & & & & 85 & \\
\hline & 100 & & & & 89 & \\
\hline
\end{tabular}

a) $13 \%$ phosphoryl amide aqueous solution ( $\mathrm{pH} 9$ )

Table 8 Degree of Swelling (S) of Natural Fibers

\begin{tabular}{llrr}
\hline Fiber & Solvent & Degree of swelling (S) & Lit. \\
\hline Silk & Water & $30-32\left(20^{\circ} \mathrm{C}\right)$ & 10 \\
& DMSO & $134\left(30^{\circ} \mathrm{C}\right)$ & 3 \\
& DMF & $34\left(30^{\circ} \mathrm{C}\right)$ & 3 \\
\hline Cotton & Water & $42-44\left(20^{\circ} \mathrm{C}\right)$ & 10 \\
& DMSO & $130\left(20^{\circ} \mathrm{C}\right)$ & 11 \\
& DMF & $60\left(20^{\circ} \mathrm{C}\right)$ & 11 \\
& EG & $10\left(20^{\circ} \mathrm{C}\right)$ & 11 \\
\hline Rayon & Water & $109-127\left(20^{\circ} \mathrm{C}\right)$ & 10 \\
& DMSO & $163\left(60^{\circ} \mathrm{C}\right)$ & 12 \\
& DMSO $\left.{ }^{3}\right)$ & $169\left(80^{\circ} \mathrm{C}\right)$ & 12 \\
& DMSO $^{\text {a }}$ & $162\left(100^{\circ} \mathrm{C}\right)$ & 12 \\
& Methanol $^{\mathrm{a}}$ & $10\left(65^{\circ} \mathrm{C}\right)$ & 12 \\
& Water $^{\mathrm{a}}$ & $81\left(100^{\circ} \mathrm{C}\right)$ & 12 \\
\hline
\end{tabular}

a) Degree of swelling (W)

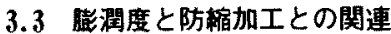

松崎〔7〕により詳細に考察されているように，瀻維
織物の収縮は水などの溶媒の膨潤に伴って起こる現象で ある。その駆動力は編織時の歪の開放であると考えられ ている。轹維自体は膨潤により綫維軸方向には極僅か，

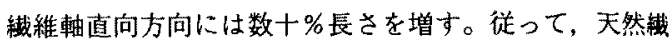
維の水による膨潤により体積は100\% 前後增加する(表 8）。表 8 に示した膨潤体皘增加率と前述の布の膨潤度

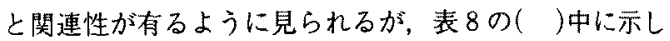
た測定温度は室温付近であり，一方室温付近での布の膨 潤度は非常に小さいことに注目したい。

沸騰水中 30 分間の漫漬で20\%前後収縮する絹(サテン 及び一越ちりめん)及びレーヨン(スフ及びフィラメン ト)をリン酸アミドを用いて防縮加工を行い収縮率を $2 \%$ 程度にした布の，加工時に使用した溶媒による膨閵 度は加工前徭で殆ど変化しない。

以上の結果を考虑して防縮機構を考察する。主鎖結合 の回転運動即ち配座の変化に依ってセグメントの搪散が 起こるに十分な熱工ネルギーを獲得する温度である2次 転位温度以下では織維に比較して布帛の膨潤速度はかな り荤い。試莧が非晶部分に比較的侵入しにくい場合には 轹維の非晶度よりも非晶部分の状態が重要であることが 知られている $(8)$ 。綟，レーヨン共非晶部分の比較的多 い織維であるが，その非晶部分にかなり構造性のある中 間領域が存在寸ると考之られている。適当な試莯と条件 の元にこれらの中間領域を固定化すれば，結晶性の高い 綿類似の物性を付与することが可能と考えられる。高分 子を溶解するためには高分子の構造単位間 1 对の凝集力 及び溶媒分子1対の凝集力を破堆して構造単位 - 溶媒分 子間 2 対を作るに必要なエネルギーを与える必要がある が、このエネルギーを見積る1つの方法に浴解度パラメ 一ターがある。しかし，高分子 - 溶媒間に强い親和力が 㗢いて混合熱及び希䣋熱が負になる場合には溶解度パラ メー夕一の定義式は成立しない[9]。DMSO，EG，水な どは綃，レーヨンなどの構造分子と強い水素結合，双榅 子相互作用が働くため溶解度パラメーターは参考資料に はなるが1：1の関係は示さない。絹の溶解度パラメー ターに近い溶媒が必ずしも良好な膨潤溶媒とはならない のはこの理由によると考えられる。

プラスチックの結晶化度はレーヨンの数分の 1 以下で あり，分子間力も弱いため延伸したプラスチックを加㷫 処理すると収縮が生ずる。緎維自体は結晶化度，配向度 も高く分子間力も強いため, 二次転位点は $60^{\circ} \mathrm{C}$ より 高い方が多く天然傤維においては $100^{\circ} \mathrm{C}$ 程度の加熱では 熱变形は起こり難い。䋐維に撚りを与え，物理的に組樴 された布は構成絨維と比較すると全体の体積から見た緹 晶化度, 配向度は極端に低下している。加撚，編織の工 程で蓄積された歪は織物の組織構造に固定されて熱運動 
のみでは歪の開放は起こらない。液体による膨潤に依っ て布が収縮するのは主としてその組織構造によると説明 されている。この点は当然考慮されねばならないと思わ れる。膨潤に伴う力は熱運動エネルギーよりかなり大き いと考えられる。膨潤に依って個々の織維及び禾の接触 点のかなりが解放され易動度が堌し，蓄積された歪の解 放即ち収縮が生ずると思われる。この歪の解放エネルギ 一は防縮加工時布全体では幅が固定されているため，そ の系での最も安定な配列に再配列されるであろう。この 再配列された状態で䄉維及び禾の接触点を化学結合で強 固に結合すれば，再膨潤の際前の膨潤時の形態で形状が 留まる可能性が高いであろう。レーヨンの場合, 洗濯回 数の增加につれて収縮率が增加する進行収縮率が実用的 に問題になるが，リン酸アミド防縮加工で進行収縮率の 低い(殆ど変わらない)加工布が得られることはこの機構 で説明できる。

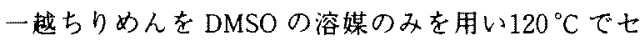
ットすると沸滕水中の処理では数回で, $\operatorname{DMSO}\left(100^{\circ} \mathrm{C}\right)$ 浸漬では 1 回で未处理の布と同様の収縮性に戻る。歪の 解放に必要であり，且つ接触点に扔ける化学結合に都合 のよい配向に必要な膨閏が綸ではDMSOで,レーヨン では水溶液で達成され，その時の膨潤度が雨者とも 100\%(あるいはそれ以上)に近いことは単なる偶然とは 考えにくい。即ち水による膨潤に依って布が収縮するの を防止するためには絹，レーヨン共100\%程度膨潤した 状態を固定化し，再膨潤の際にはランダム構造部分の伸 長によって溶媒を受け入れ，結節点(恐らく結晶を含め た架橋部分及び加工剤の接着効果や布の組織構造に基づ
(物理的接触点)部分が構造の寸法安定性に奇与してい ると考えられる。実際絧采或はレーヨン采を上述の防縮 加工条件で処理した采はかなりの力を加えて変形を与之 た後でも膨潤させると防縮加工時の形態に戻る形状記憶 性を繰り返すことが可能である。

\section{文献}

1. 浅井紀夫，林 良之，岡川逸郎，日晎雑，58，77 (1989)

2. 浅井紀夫，林 良之，岡川逸郎，日虫雑， 58，398 (1989)

3. 北村爱夫，柴本秋男，出村 誠，日亘雑， 59，43 (1990)

4. 平林 潔, 大木飠一, 荒井三雄, 重松正矩, 日㫫 雑, 49，39（1980）

5. 礪波宏明, A. S. M. Shahid, 北原幹夫, 䋐学誌, 33, T-115 (1977)

6. 大門 優, 笹倉忠雄, 林 良之, 日本緎維機械学会 予稿集, p. 151 (1989)

7. 松绮清一郎,「織物の樹脂加工」, 丸善, p. 267 (1955)

8. 桜田一郎, 坂口康義, 䋞学誌, 13，13（1957）

9. 織維学会編, 「瀻維便覧，原料編」，丸善， p. 63 (1968)

10. 樴維学会編, 「辅維物理学」, 丸善, p. 180 (1962)

11. O. Annenn, Melliand Textilber., 54, 387 (1973)

12. 池田功夫, 陳 耿明, 鈴木公宏, 木戸猪一郎, 織学 誌, 33, T-95 (1977) 